DOI: https://doi.org/10.24867/16CG07Milasinovic

\title{
АНАЛИЗА РАЗЛИЧИТИХ ВРСТА АСФАЛТНИХ СЛОЈЕВА ЗА РЕКОНСТРУКЦИЈУ КОЛОВОЗА НА ДРЖАВНОМ ПУТУ ІІ А РЕДА БРОЈ 113 КИСАЧ - СТЕПАНОВИЋЕВО
}

\section{ANALYSIS OF DIFFERENT TYPES OF ASPHALT LAYERS FOR ROAD RECONSTRUCTION ON STATE ROAD II ROW A NUMBER 113 KISAČ - STEPANOVIĆEVO}

\author{
Радмила Милашиновић, Факултет техничких наука, Нови Сад
}

\begin{abstract}
Област - ГРАЂЕВИНАРСТВО
Кратак садржај - У раду је приказана анализа различитих врста асфалтних слојева за реконструкиију државног пута II А реда број 113 Кисач Степановићево, као и утииај температуриних промена на коловозну конструкиију по сезонама (зима,јесен/пролеће и лето). Анализа напона и деформачија за свих шест варијантних решења изврмена је помоћу програмског пакеета "BISAR", док је анализа утииаја температурних промена урађена помоћу софтвера SPDM. Анализа различитих врста асфалтних слојева вршена је како би се усвојило најбоље варијантно решене за реконструкиију државног пута Кисач - Степановићево.
\end{abstract}

Кључне речи: анализа, варијантна решења, реконструкиија

Abstract - This work presents an analysis of different types of asphalt layers for the reconstruction of the state road II A row numbre 113 Kisač - Stepanovićevo, as well as the impact of temperature changes on the road structure by seasons (winter, autumn / spring and summer). Stress and strain analysis for all six variant solutions was performed using the software package „BISAR" while the analysis of the impact of temperature changes was performed using SPDM software. The analysis of different types of asphalt layers was performed in order to adopt the best variant solution for the reconstruction of the state road Kisač Stepanovićevo.

Keywords: analysis, variant solutions, recostruction

\section{1. УВОД}

Коловозна конструкција се састоји од више слојева невезаног и (везивом) везаног минералног агрегата положених на постељицу.

Основни критеријуми за правилно функционисање коловозне конструкције у погледу трајности, конструктивних карактеристика, сигурности и удобности вожње су:

\section{НАПОМЕНА:}

Овај рад је проистекао из мастер рада чији ментор је био доц. др Милош Шешлија.
- Да је постављена на добро носиву подлогу (постељицу) и да има довољну дебљину да издржи очекивано саобраћајно оптерећење;

- Да омогући ефикасно одвођење воде са површине коловоза, да спречи продирање воде са коловоза у труп пута као и скупљање воде унутар коловозне конструкције;

- Да има раван површински слој, потребно храпав, отпоран на хабање и утицај атмосферијлија и хемикалија.

Постоје два основна типа савремених коловозних конструкција, а то су флексибилне и круте коловозне конструкције. Основни елементи коловозне конструкције су застор и подлога [1].

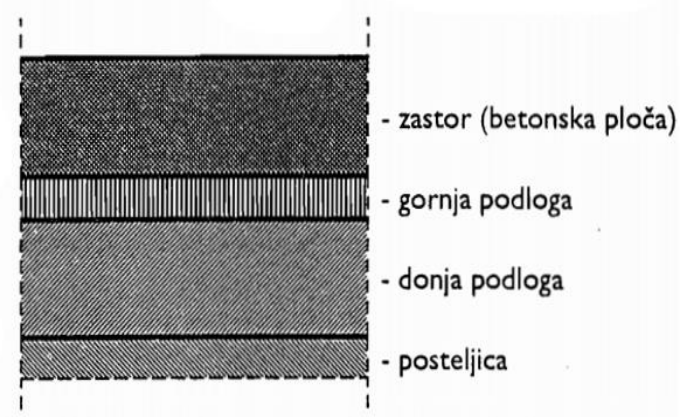

Слика 1. Крута коловозна конструкција

Код крутих коловозних конструкција, застор чини бетонска плоча. Плоча од цемент бетона, па се обично назива бетонски коловоз. Испод плоче су доња и горња подлога. Квалитет материјала и величина напрезања у коловозној конструкцији опада од застора ка постељици (слика 1).

Број и дебљина слојева као и квалитет материјала од којих се слојеви праве одређују се у поступку димензионисања. У неким случајевима поједини слојеви коловозне конструкције се могу изоставити када је постељица од песка или камена.

У односу на круте коловозне конструкције, флексибилне конструкције су еластичније и деформабилније. Њихова предност је у брзини грађења, једноставнијем одржавању, а нарочито у удобности вожње. 
С друге стране круте коловозне конструкције преносе оптерећење на много већу површину постељице. Појам савремене флексибилне коловозне конструкције обухвата вишеслојну конструкцију, која се састоји од слојева битуменом везаних камених агрегата, тј. од асфалтног и носећих слојева (везани и невезани материјали) који су произведени и уграђени по савременој технологији (слика 2 и слика 3) [1].

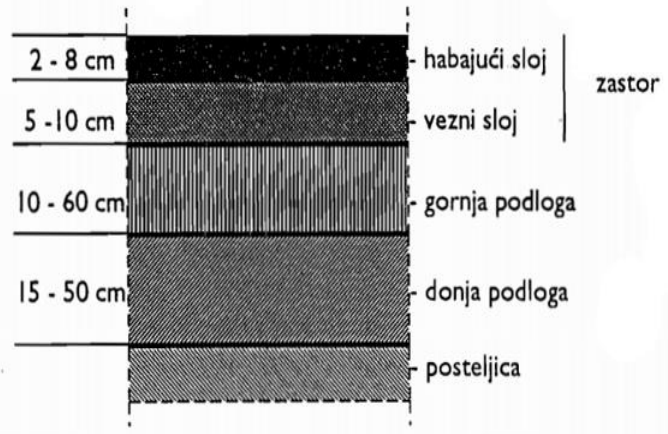

Слика 2. Флексибилна коловозна конструкција

Састав, дебљина и распоред слојева за поједине типове флексибилних коловозних конструкција највише зависи од саобраћајног оптерећења, својства тла у постељици и климатско хидролошких услова. За избор типа коловозне конструкције понекад су одлучујуће могућности набавке појединих материјала и њихова цена [2].

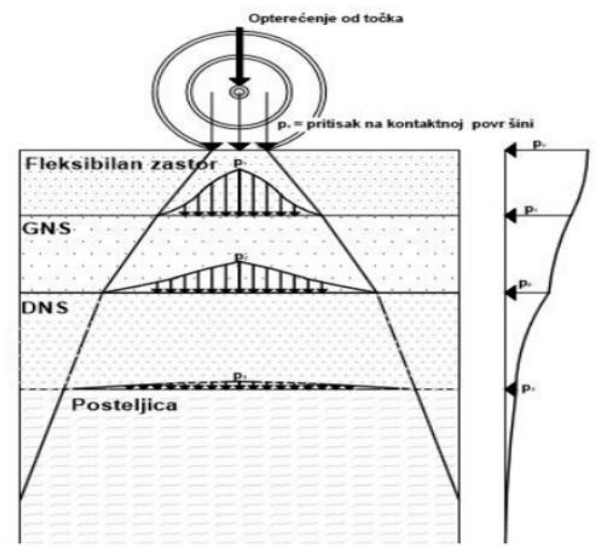

Слика 3. Распоред оптерећења-иема преноса оптерећена од осовине возила дроз слојеве коловозне конструкиије, постељииу и подтло [2]

\section{2. АНАЛИЗА ВАРИЈАНТНИХ РЕШЕЊА}

Предмет ове анализе јесте избор најбољег варијантног решења за реконструкцију државног пута Кисач Степановићево.

Прорачун напона и деформација се заснива на претпоставци да се коловозна конструкција може представити као вишеслојни еластични систем.

С обзиром на очекивано саобраћајно оптерећење које се очекује у експлоатационом периоду на основу стандарда за битуменом везане слојеве усвојене су следеће мешавине из табеле (Табела 1.).

Прорачун модула крутости асфалтних слојева урађен je према SHELL методологији помоћу програма BANDS 2.0.

\begin{tabular}{|c|c|c|c|c|}
\hline Мешавина & $\begin{array}{c}\text { Температура } \\
\text { слоја }\left({ }^{\circ} \mathrm{C}\right)\end{array}$ & $\begin{array}{l}\text { Својства } \\
\text { остарелог } \\
\text { битумена }\end{array}$ & $\begin{array}{l}\text { Запреминско } \\
\text { учешће } \\
\text { компоненти у } \\
\text { асфалтној } \\
\text { мешавини }\end{array}$ & $\begin{array}{l}\text { Модул крутости } \\
\text { мешавине за } \\
\text { брзину } \mathrm{V}=60 \mathrm{~km} / \mathrm{h} \\
(\mathrm{t}=0,02 \mathrm{~s})\end{array}$ \\
\hline $\begin{array}{c}\text { АБ } 11 \mathrm{c} \text { са ПмББ } \\
45 / 80-65\end{array}$ & 21 & $\begin{array}{l}\text { Pen }=39 \\
\text { Tpk }=60 \\
\mathrm{Pl}=0,4\end{array}$ & $\begin{array}{l}V b=12 \% \\
V a=83 \% \\
V v=5 \%\end{array}$ & $3850 \mathrm{MPa}$ \\
\hline $\begin{array}{c}\text { АБ } 16 \mathrm{c} \mathrm{ca} \mathrm{ПмБ} \\
45 / 80-65\end{array}$ & 21 & $\begin{array}{l}\mathrm{Pen}=39 \\
\mathrm{Tpk}=60 \\
\mathrm{Pl}=0,4\end{array}$ & $\begin{array}{c}V b=12,5 \% \\
V a=83 \% \\
V v=4,5 \%\end{array}$ & $3800 \mathrm{MPa}$ \\
\hline $\begin{array}{l}\text { БНС } 22 \mathrm{cA} \mathrm{ca} \\
\text { ПмБ 45/80-65 }\end{array}$ & 20 & $\begin{array}{l}\text { Pen }=39 \\
T p k=60 \\
P l=0,4\end{array}$ & $\begin{array}{l}V b=8,3 \% \\
V a=86 \% \\
V v=5,7 \%\end{array}$ & $6190 \mathrm{MPa}$ \\
\hline $\begin{array}{c}\text { АБ } 11 \mathrm{c} \mathrm{ca} \mathrm{БИТ} \\
50 / 70\end{array}$ & 21 & $\begin{array}{c}\text { Pen=39 } \\
\text { Tpk }=56,4 \\
\mathrm{PI}=-0,3\end{array}$ & $\begin{array}{l}V b=12 \% \\
V a=83 \% \\
V v=5 \%\end{array}$ & $4400 \mathrm{MPa}$ \\
\hline $\begin{array}{c}\text { АБ } 16 \mathrm{c} \mathrm{cа} \mathrm{БИТ} \\
50 / 70\end{array}$ & 21 & $\begin{array}{c}\text { Pen=39 } \\
T p k=56,4 \\
P I=-0,3\end{array}$ & $\begin{array}{c}V b=11,5 \% \\
V a=83 \% \\
V v=5,5 \%\end{array}$ & $4490 \mathrm{MPa}$ \\
\hline $\begin{array}{c}\text { БНС 22cA ca } \\
\text { БИТ 50/70 }\end{array}$ & 20 & $\begin{array}{c}\text { Pen=39 } \\
\text { Tpk }=56,4 \\
\mathrm{PI}=-0,3\end{array}$ & $\begin{array}{l}V b=8,3 \% \\
V a=86 \% \\
V v=5,7 \%\end{array}$ & $7020 \mathrm{MPa}$ \\
\hline
\end{tabular}

Табела 1. Приказ модула крутости асфалтних слојева [3]

Критичне дилатације за димензионисање флексибилних коловозних конструкција су: дилатације затезања на дну битуменом везаних слојева - пукотине услед замора (одоздо на горе); дилатација (напон) затезања на дну цементом везаних слојева - пукотине услед замора (одоздо на горе); дилатација притиска на површини постељице - трајна деформација постељице и дилатација затетзања на површини коловоза - пукотине услед замора (подужне пукотине, одозго на доле) (слика 4 и слика 5).

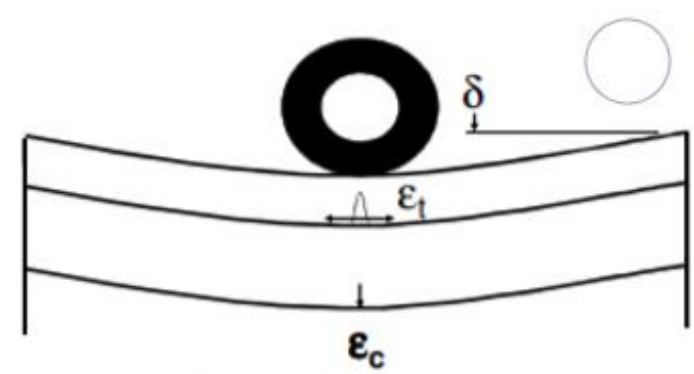

Слика 4. Приказ утицаја критичних дилатащија на коловозну конструкиију (пукотине одоздо на горе) [1]

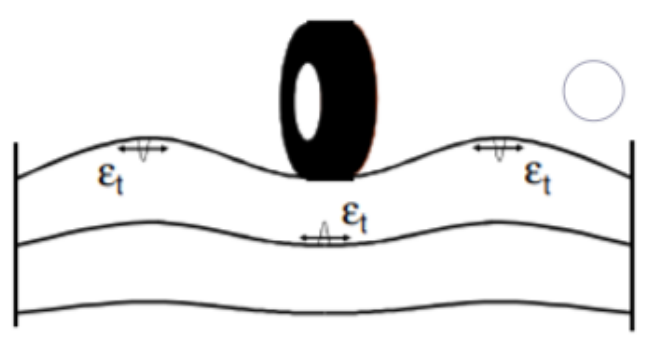

Слика 5. Приказ утицаја критичних дилатащија на коловозну конструкцију (подужне пукотине - одозго на доле) [1]

Анализа је вршена на шест могућих варијантних решења и то:

1) ВАРИЈАНТА I: АБ 11 с са ПмБ 45/80-65 + БНС 22сA са ПмБ 45/80-65

2) ВАРИЈАНТА ІІ: АБ 16 с са ПмБ 45/80-65 + БНС 22сА са ПмБ 45/80-65 
3) ВАРИЈАНТА ІІІ: АБ 11 с са БИТ 50/70 + БНС 22cА са БИТ 50/70

4) ВАРИЈАНТА ІV: АБ 16с са БИТ 50/70 + БНС 22cА са БИТ 50/70

5) ВАРИЈАНТА V: АБ $11 \mathrm{c} \mathrm{са} \mathrm{ПмБ} \mathrm{45/80-65} \mathrm{+} \mathrm{БНС}$ 22сА са БИТ 50/70

6) ВАРИЈАНТА VI: АБ 16с са ПмБ 45/80-65 + БНС 22cА са БИТ 50/70

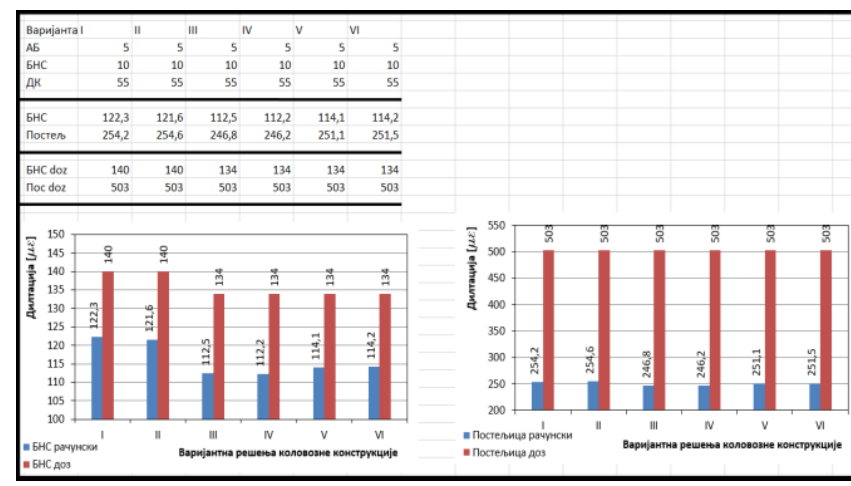

Слика 6. Табеларни приказ рачунских и дозвољених вредности дилатащија за БНС и постељьиу

Најмање вредности деформације у доњим асфалтним слојевима јављају се код варијантног решења 4, односно код комбинације АБ 16с са БИТ 50/70 + БНС 22cА са БИТ 50/70 чија је дилатација $\varepsilon=112,2$ $\mu \mathrm{m}$, док се максималне вредности јављају код варијантног решења 1, односно код комбинације АБ 11с са ПмБ 45/80-65 + БНС 22сА са ПмБ 45/80-65 чија је дилатација $\varepsilon=122,3 \mu \mathrm{m}$ (слика 6).

Најмање вредности код варијантног решења 4 настају из разлога великог модула еластичности који за АБ 16 с износи $\mathrm{E}=4490 \mathrm{MPa}$ и за БНС $22 \mathrm{cA}$ износи $\mathrm{E}=7020 \mathrm{MPa}$, док максималне вредности настају због малог модула еластичности који код варијантног решења 1 за АБ 11 с износи $\mathrm{E}=3850 \mathrm{MPa}$ и за БНС 22cА износи E $=6190 \mathrm{MPa}$. Следеће варијантно решење одмах после најмање вредности деформације у доњим асфалтним слојевима је варијантно решење 3, односно комбинација АБ 11с са БИТ 50/70 + БНС 22cА са ПмБ 45/80-65 чија је дилатација $\varepsilon=112,5 \mu \mathrm{m}$. Код овог варијантног решења модул еластичности за АБ 11 с износи $\mathrm{E}=4400 \mathrm{MPa}$, док је модул еластичности за БНС 22cA=7020 МРa (слика 6).

Разлика између варијантног решења 3 и 4 је у вредности модула еластичности за асфалт бетон који се разликује за $90 \mathrm{MPa}$.

Анализом варијантних решења закључујемо да, што је модул еластичности већи деформације у асфалтним слојевима ће бити мање, односно што је модул еластичности мањи деформације у асфалтним слојевима ће бити веће.

Што се тиче деформације постељице, минималне деформације ће се јавити код варијантног решења 4 , чија је дилатација $\varepsilon=246,2 \mu \mathrm{m}$, док ће се максималне вредности деформације јавити код варијантног решења 2 , чија је дилатација $\varepsilon=254,6 \mu \mathrm{m}$. Модул еластичности посетљице за сва варијантна решења износи $50 \mathrm{MPa}$.

\section{3. УТИЦАЈ ТЕМПЕРАТУРНИХ ПРОМЕНА НА КОЛОВОЗНУ КОНСТРУКЦИЈУ}

Температурни напони који настају у коловозним конструкцијама обухватају напоне услед савијања и извијања, напоне при трењу и притајене напоне. Напони који су изазвани дејством температуре у коловозној конструкцији током дана су углавном испод чврстоће употребљених материјала тако да се не јављају последице по конструкцију. Међутим, долази до појаве заосталих напона чијом акумулацијом после довољно дугог временског периода може доћи до појаве лома у конструкцији, односно термичког замора материјала. Спољни фактори који утичу на температуру слојева и на понашање материјала проистичу из климатских карактеристика, а манифестују се преко температуре ваздуха, сунчане радијације и ветра. Спољни фактори су првенствено зависни од географске локације на којој се налази изграђена коловозна конструкција.

Унутрашњи фактори утицаја на коловозне конструкције обухватају емитовање великих таласа радијације из тла и термичка својства материјала коловозне конструкције и постељице. Они су зависни од геолошке грађе терена. У односу на спољне факторе, који могу бити променљиви, унутрашњи се за одређену локацију могу сматрати приближно сталним.

Истраживања су показала да је температура на површини асфалтног застора коловозне конструкције углавном виша од температуре ваздуха. Разлог томе је сунчана радијација, односно упијање топлоте у црну површину асфалта.

Температура утиче на механичка и реолошка својства свих материјала у коловозној конструкцији, при чему је највећи утицај изражен на асфалтне слојеве.

Асфалт је материјал који на високим температурама има високоеластичне карактеристике, а на ниским високопластичне. При високим температурама долази до течења, док при ниским температурама долази до пластичности.

При ниским температурама (мањим од $-15^{\circ} \mathrm{C}$ ) могу да се појаве попречне пукотине због појаве термичких напона који превазилазе чврстоћу на затезање.

Материјали у коловозној кострукцији се у току дана различито загревају и хладе. Напрезање у коловозној конструкцији при цикличној промени температуре настаје као директна последица промене запремине којој су подложни сви материјали, чему додатно доприноси међусобна повезаност свих слојева. Ако су та напрезања толико велика да материјали нису у могућности да их поднесу, долази до штетних појава у коловозној конструкцији, пукотина или деформација. Потребно је пројектовати коловозну конструкцију која ће се одупрети овим утицајима.

За потребе прорачуна сезонских температура ваздуха примењени су подаци о средњим температурама ваздуха меренх у мерној станици Нови Сад у периоду од 2010. до 2019. године. Ови подаци су приказани у наредној табели (табела 2 и табела 3 ). 


\begin{tabular}{|c|c|c|c|c|c|c|c|c|c|c|c|c|c|}
\hline $\begin{array}{c}\text { Редни } \\
\text { број }\end{array}$ & година & јан. & феб. & март & април & мај & јун & јул & авг. & септ. & окт. & нов. & дец. \\
\hline 1 & 2010. & 0,4 & 2,9 & 6,8 & 12,5 & 16,9 & 20,6 & 23,0 & 22,4 & 16,8 & 9,8 & 10,8 & 0,6 \\
\hline 2 & 2011. & 0,2 & $-0,8$ & 6,3 & 12,9 & 16,7 & 21,2 & 22,6 & 22,7 & 20,5 & 10,4 & 2,6 & 3,4 \\
\hline 3 & 2012. & 0,7 & $-4,2$ & 7,4 & 13,2 & 16,5 & 22,7 & 25,3 & 22,2 & 19,3 & 12,5 & 9,2 & 0,7 \\
\hline 4 & 2013. & 1,9 & 4,0 & 5,4 & 13,2 & 18,5 & 20,3 & 22,8 & 23,7 & 15,5 & 13,4 & 9,4 & 1,9 \\
\hline 5 & 2014 & 3,1 & 5,8 & 9,0 & 12,7 & 16,1 & 20,1 & 22,1 & 21,2 & 16,9 & 12,9 & 8,4 & 2,6 \\
\hline 6 & 2015. & 2,1 & 3,3 & 7,1 & 11,5 & 17,6 & 20,7 & 24,9 & 24,5 & 20,0 & 11,7 & 6,9 & 2,8 \\
\hline 7 & 2016. & $-0,1$ & 7,6 & 7,6 & 14,0 & 15,9 & 21,6 & 22,5 & 20,7 & 17,3 & 10,2 & 6,4 & $-0,8$ \\
\hline 8 & 2017. & $-3,9$ & 3,2 & 10,1 & 11,7 & 17,1 & 22,7 & 24,4 & 23,1 & 17,1 & 11,3 & 7,0 & 2,8 \\
\hline 9 & 2018. & 3,1 & 2,2 & 5,7 & 16,9 & 19,5 & 21,0 & 21,9 & 23,5 & 17,9 & 14,4 & 8,1 & 1,6 \\
\hline 10 & 2019. & $-0,3$ & 3,6 & 9,5 & 13,2 & 14,9 & 22,9 & 22,7 & 23,8 & 18,9 & 14,3 & 11,7 & 4,7 \\
\hline
\end{tabular}

Табела 2. Средње температуре ваздуха

\begin{tabular}{|c|c|c|c|c|c|c|c|c|c|c|c|c|}
\hline Месец & јан. & феб. & март & април & мај & јун & јул & авг. & септ. & окт. & нов. & дец. \\
\hline $\begin{array}{l}\text { Средње } \\
\text { температуре } \\
\text { ваздуха ( }{ }^{\circ} \text { C) }\end{array}$ & 0,7 & 2,8 & 7,5 & 13,2 & 17,0 & 21,4 & 23,2 & 22,8 & 18,0 & 12,1 & 8,1 & 2,0 \\
\hline
\end{tabular}

Табела 3.. Средње месечне температуре ваздуха

На основу података о средњим месечним температурама ваздуха одређују се меродавне средње месечне температуре ваздуха $\mathrm{w}$ - MAAT $\left({ }^{\circ} \mathrm{C}\right)$ и меродавне средње месечне температуре у асфалтним слојевима коловозне конструкције w-MAPT $\left({ }^{\circ} \mathrm{C}\right)$ по решењу Shall лабораторије, која даље служи за одређивање динамичких модула еластичности асфалтних слојева у коловозној конструкцији при структурној анализи прелиминарних решења. У наредној табели су приказане меродавне температуре ваздуха и асфалтних слојева за три периода током године (зима, пролеће/јесен и лето) (табела 4).

\begin{tabular}{|c|c|c|c|c|}
\hline Температура & зима & пролеће & лето & јесен \\
\hline w-MАAT $\left({ }^{\circ} \mathrm{C}\right)$ & 1,9 & 13,5 & 22,5 & 13,8 \\
\hline w-MAРT $\left({ }^{\circ} \mathrm{C}\right)$ & 1,8 & 20,2 & 33,4 & 20,6 \\
\hline
\end{tabular}

Табела 4. Меродавне температуре ваздуха и асфалтних слојева

\section{4. ЗАКЉУЧАК}

Након анализирања свих шест случајева варијантних решења, закључује се да свако од датих варијантних решења испуњава услове у погледу напона и деформације.

Разлике између добијених резултата нису велике, па стога свих шест врста варијнатних решења би могле бити искоришћене за реконструкцију пута Кисач Степановићево.

\section{5. ЛИТЕРАТУРА}

[1] Александар Цветановић, Боривоје Банић: „Коловозне конструкције“, Београд 2007.

[2] Ђорђе Узелац: , Путеви и градске саобраћајнице“, ФТН издаваштво, Нови Сад 2015.

[3] Петар Суботић, Приручник за асфалт, II издање, Београд 2002.

\section{Кратка биографија:}

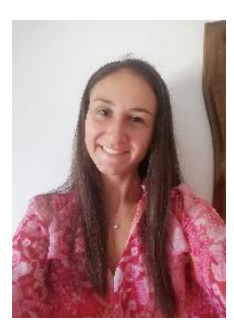

Радмила Милашиновић рођена је 1996. године. у Новом Саду, Република Србија. Мастер рад на Факултету техничких наука из области Грађевинарства - Путеви, железнице и аеродроми одбранила је 2021. године.

Контакт:milasinovic35@gmail.com 